\title{
Integrasi Media Peta (Tematik) Persebaran Candi Hindu-Buddha Di Tulungagung Dengan Pendekatan Kontruktivisme Dalam Pembelajaran Sejarah
}

\author{
Danan Tricahyono, Akhmad Arif Musadad, Triana Rejekiningsih \\ danancahyono2@gmail.com \\ Universitas Sebelas Maret
}

\begin{abstract}
Historical learning is ideally held creatively and innovatively. The purpose of this study is to provide an alternative framework for historical learning through a map (thematic) distribution of Hindu-Buddhist temples in Tulungagung with a constructivist approach. The methods used in research are qualitative and disbursed research. Data collection techniques use observations, interviews, and various libraries from books, articles, and research report results. Different library materials are identified, analyzed, and reflected to create new findings. As a result, there are seven Hindu-Buddhist temple sites in Tulungagung, namely Boyolangu Temple, Sanggrahan Temple, Table Temple, Dadi Temple, Mirigambar Temple, Ampel Temple, and Penampihan Temple. The narrative about the seven temples is used as content (content) of the map media. The implementation of map media is integrated with the constructivism approach through the learning cycle model. The learning cycle stages include discovery, concept recognition, and concept applications. In conclusion, combining local historical materials can strengthen students' awareness of local history.
\end{abstract}

Keywords: learning, history, temple, Tulungagung, constructivism

\begin{abstract}
Abstrak
Pembelajaran sejarah idealnya diselenggarakan secara kreatif dan inovatif. Tujuan penelitian ini memberikan alternatif kerangka pembelajaran sejarah melalui peta (tematik) persebaran candi Hindu-Buddha di Tulungagung dengan pendekatan konstruktivisme. Metode yang digunakan dalam penelitian yaitu kualitatif dan riset kepustakaan. Teknik pengumpulan data menggunakan observasi dan wawancara serta berbagai sumber pustaka dari buku, artikel dan hasil laporan penelitian. Berbagai bahan pustaka diidentifikasi, dianalisis dan direfleksikan sehingga tercipta temuan baru. Hasilnya terdapat tujuh situs candi Hindu-Buddha di Tulungagung yaitu Candi Boyolangu, Candi Sanggrahan, Candi Meja, Candi Dadi, Candi Mirigambar, Candi Ampel, dan Candi Penampilan. Narasi tentang tujuh candi tersebut digunakan sebagai konten (isi) dari media peta. Implementasi media peta terintegrasi dengan pendekatan konstruktivisme melalui model siklus belajar. Tahapan siklus belajar meliputi discovery (penemuan), pengenalan konsep, dan aplikasi konsep. Kesimpulannya integrasi materi sejarah lokal dapat menguatkan kesadaran sejarah lokal siswa.
\end{abstract}

Kata Kunci: pembelajaran, sejarah, candi , Tulungagung, konstruktivisme 
Integrasi Media Peta (Tematik) Persebaran Candi Hindu-

Buddha Di Tulungagung Dengan Pendekatan

Kontruktivisme Dalam Pembelajaran Sejarah

\section{Pendahuluan}

Menghadirkan pembelajaran sejarah secara kekinian penting dilakukan oleh guru. Upaya tersebut dapat dilakukan dengan mengikuti tren pembelajaran abad 21. Salah satu bentuk adaptasi mata pelajaran sejarah terhadap pola pembelajaran abad 21 dengan memanfaatkan teknologi informasi dan komunikasi guna meningkatkan efektivitas dan efisiensi pembelajaran. Guru mengintegrasikan media ke dalam pembelajaran di kelas. Media pembelajaran memiliki fungsi menyaksikan benda atau peristiwa di masa lampau. Melalui media tersebut siswa dapat memperoleh gambaran yang nyata tentang peristiwanya. Media juga memberikan kemudahan ke siswa untuk mengamati benda yang sukar atau jauh letaknya sehingga mudah untuk diamati (Gerlach \& Ely, 1980).

Media pembelajaran apabila terintegrasi dengan pembelajaran dapat menciptakan pembelajaran yang inovatif dan menarik. Konsep sejarah yang erat dengan waktu, spasial, dan tempat membutuhkan media guna mengkongritkan aspek spasial dan tempat. Asumsi ini didukung oleh penelitian dari Ningsih, Sariyatun, \& Sutimin (2019) menunjukkan jika materi sejarah yang tidak dikemas secara benar berpengaruh terhadap pemahaman siswa menjadi abstrak. Pengaruhnya siswa kurang menghayati nilai-nilai yang ada dalam mata pelajaran sejarah. Dengan demikian keberadaan media penting dalam pembelajaran sejarah guna tercapainya tujuan dari belajar sejarah. Bersandar pada amanah kurikulum harapannya siswa memiliki kompetensi sikap, pengetahuan, dan keterampilan. Kompetensi sikap berhubungan dengan perilaku toleran (empati) dalam kehidupan berbangsa dan bernegara serta memiliki kesadaran sejarah dan nasionalisme. Kompetensi pengetahuan berhubungan dengan kemampuan berpikir historis. Kompetensi keterampilan berkaitan dengan penelitian sejarah secara sederhana (Agung, 2015). Ketika kompetensi tersebut bisa dicapai oleh para siswa akan menjadikannya pribadi yang unggul. Sebagaimana muara dari belajar sejarah yaitu menciptakan manusia cerdas ditopang dengan karakter yang baik (Bandarsyah, 2014).

Permasalahannya belum semua guru mengintegrasikan media secara tepat dalam pembelajaran sejarah yang diselenggarakannya. Pengaruhnya terjadi distorsi pemahaman siswa terhadap materi sejarah. Hal ini dibuktikan dengan kondisi pembelajaran sejarah di MAN 2 Tulungagung. Pada saat guru menanyakan informasi mengenai lokasi candi Sanggrahan, siswa memberikan respon jika lokasi candi tersebut berada di kabupaten Blitar. Siswa bingung membedakan candi Penataran dan candi Sanggrahan. Hal ini membuktikan jika pemahaman aspek spasial siswa masih belum optimal. Aspek spatial identik 
dengan ruang terjadinya peristiwa sejarah. Aspek spasial selalu bersinggungan dengan tempat terjadinya peristiwa sejarah. Guna membantu pemahaman siswa terhadap materi sejarah supaya komprehensif maka diperlukan solusi alternatif.

Solusi untuk membantu siswa supaya memiliki pemahaman komprehensif berkaitan dengan aspek waktu, spatial, dan tempat dengan mendesain media pembelajaran sejarah berbasis peta tematik. Keberadaan peta sebagai media pembelajaran memiliki beberapa keunggulan diantaranya untuk menghadirkan objek sebenarnya, menjadikan konsep abstrak menjadi lebih konkret, menyamakan persepsi, mengatasi hambatan jarak, waktu, dan tempat, memberi suasana pembelajaran yang menarik dan menyenangkan (Arsyad, 2019). Penekanan tematik dalam pembuatan peta kaitannya dengan konten (isi) materi. Dalam hal ini materinya fokus pada situs-situs candi di Tulungagung. Materi tersebut dipilih sebagai konten dari peta dengan pertimbangan kesesuaian dengan kompetensi dasar (KD) dan aspek lokalitas materi yang berada di sekitar lingkungan sekolah.

Pemilihan konten media berbasis materi lokal lebih berpengaruh terhadap sisi emosinal siswa. Pendapat tersebut didukung oleh Hasan (2019) menjelaskan bahwa materi pembelajaran yang dekat dengan siswa akan berpengaruh secara psikologis. Hal ini karena siswa lebih mudah bersinggungan dengan perubahan yang berada di sekitarnya. Para siswa belajar mengenai apa yang telah terjadi di masa lalu tetapi juga menyadari masa kini sebagai bagian dari masa lalu. Perubahan yang terjadi di masa lalu yang terus berlanjut pada masa kini memberikan landasan berpikir serta modal untuk bersikap yang positif guna mengadaptasi setiap perubahan untuk membangun kehidupan yang lebih baik sebagai manusia Indonesia yang siap menyongsong masa depan.

Supaya lebih optimal keberadaan media peta perlu dielaborasikan dengan pendekatan pembelajaran. Asumsi tersebut didukung oleh penelitian dari Ciputra \& Riyanto (2020) yang membuat peta puzle dengan pendekatan contextual teaching learning (CTL) efektif untuk meningkatkan hasil belajar. Berangkat dari hal tersebut peneliti memberikan alternatif pendekatan konstruktivisme. Melalui pendekatan konstruktivisme akan menghasilkan pembelajaran yang lebih bermakna. Asumsi peneliti didukung Widja (2018) yang menyatakan bahwa melalui pendekatan konstruktivisme, posisi siswa selama pembelajaran dipandang oleh guru sebagai pribadi yang mandiri untuk membangun pengetahuannya sesuai dengan pengalaman serta pemahamannya. Dengan demikian siswa dipandang mampu mengonstruksi 
Integrasi Media Peta (Tematik) Persebaran Candi Hindu-

Buddha Di Tulungagung Dengan Pendekatan

Kontruktivisme Dalam Pembelajaran Sejarah

pengetahuannya secara mandiri sampai bisa memberi makna terhadap hasil belajar. Hal serupa juga diungkapkan oleh Mohammed \& Kinyo (2020) melalui pendekatan konstruktivisme menjadikan siswa mampu berpikir kritis dan reflektif dalam pembelajaran, menghasilkan ide-ide baru dan menghasilkan solusi-solusi yang inovatif dalam menghadapi realitas sosial.

Beberapa penelitian terdahulu tentang peta diantaranya dilakukan oleh Hidayat (2018) mengenai penggunaan media peta pengaruhnya terhadap motivasi belajar sejarah. Kurniawan, Suryani, \& Djono (2019) mengenai pengembangan media peta sejarah berbasis macromedia flash sebagai sarana siswa belajar mandiri. Rusdiana \& Heryati (2020) mengenai pengajaran menggunakan peta sejarah dan brosur melalui model paikem (pembelajaran aktif, inovatif, kreatif dan menyenangkan) bagi guru. Penelitian ini mengisi posisi gap dari beberapa penelitian terdahulu dengan mendesain media peta (tematik) persebaran candi Hindu-Buddha yang terintegrasi dengan pendekatan konstruktivisme. Dengan berlandaskan pemaparan tersebut penelitian ini bertujuan untuk memberikan kerangka pembelajaran sejarah pada periode Hindu-Buddha melalui materi persebaran candi Hindu-Buddha di Tulungagung dengan pendekatan konstruktivisme.

\section{Metode Penelitian}

Penelitian ini menggunakan metode kualitatif dan riset kepustakaan. Peneliti menggunakan metode kualitatif untuk menyusun studi pendahuluan. Teknik pengumpulan data yang digunakan dengan observasi dan wawancara (Creswell, 2012). Peneliti melakukan observasi kegiatan pembelajaran sejarah di MAN 2 Tulungagung. Peneliti melakukan wawancara dengan guru dan siswa tentang kondisi pembelajaran sejarah. Sementara riset pustaka digunakan untuk menyusun materi tentang candi Hindu-Buddha di Tulungagung dan model implementasi media peta (tematik) candi Hindu-Buddha dengan pendekatan konstruktivisme di kelas. Peneliti memilih bahan pustaka yang sesuai dengan topik. Bahan pustaka berasal dari buku dan artikel. Bahan pustaka yang telah dikumpulkan selanjutnya dikelompokkan berdasarkan tingkat relevansi dengan topik penelitian guna memudahkan proses identifikasi. Bahan pustaka diidentifikasi sesuai dengan kebutuhan terhadap materi percandian Hindu-Buddha di Tulungagung. Pustaka yang peneliti gunakan sebagai pijakan untuk menarasikan situs percandian di Tulungagung bersumber pada tulisan Sedyawati, Dkk (2013) Candi Indonesia Seri Jawa. Selain itu juga peneliti menggunakan pustaka pendukung seperti hasil laporan penelitian sebagai data pendukung. Hasil analisis dan sintesis terhadap berbagai bahan pustaka kemudian direfleksikan dengan dipadukan teori-teori 
pembelajaran sehingga terbentuk kerangka konseptual seperti tulisan berikut ini (Zed, 2008).

\section{Hasil dan Pembahasan}

\section{Candi Hindu-Buddha di Tulungagung}

Tulungagung secara administratif berada di Provinsi Jawa Timur. Tulungagung mempunyai sejarah panjang dari masa ke masa. Salah satunya pada masa Hindu-Buddha. Bukti peninggalan Hindu-Buddha untuk bidang arsitektur dapat ditelusuri melalui beberapa candi yang tersebar di beberapa kecamatan. Pertama, Candi Boyolangu yang biasa oleh masyarakat disebut dengan Candi Gayatri. Candi Boyolangu berlokasi di Dusun Dadapan, Desa Boyolangu, Kecamatan Boyolangu, Kabupaten Tulungagung pada ketinggian 103 mdl. Secara koordinat terletak di $8^{\circ} 6^{\prime}$ 59, 400'” LS dan 111 53 21,200 BT. Candi tersebut dibangun sekitar tahun 1291 Saka (1369M) dan 1311 Saka (1389 M). Bukti yang menunjukkan angka tahun tersebut dipahatkan pada dua buah umpak yang terdapat di kompleks candi (Darmawan, Daryaka, \& Mustofa, 2016). Mengacu pada angka tahun pembangunan, candi Boyolangu dibangun pada masa pemerintahan Hayam Wuruk (1350-1389M).

Agus Aris Munandar menggolongkan Candi Boyolangu sebagai bangunan rsi. Hal ini dapat diidentifikasi lokasinya di daerah terpencil serta arsitekturnya. Sementara itu, Hariani Santiko menggolongkan Candi Boyolangu ke dalam candi dengan bergaya arsitektur Candi Naga. N.J. Krom menyebut Candi Boyolangu sebagai Punden Gilang. Sementara Th. G. Pigeaud mengungkapkan jika Candi Boyolangu termasuk dalam jenis candi Dharma Haji, yakni candi-candi yang dimiliki oleh keluarga kerajaan. Dalam hal ini kerajaan Majapahit. Fungsi candi sebagai pendharmaan (pemuliaan) berhubungan dengan penyebutan nama Candi Boyolangu sebagai Candi Gayatri.

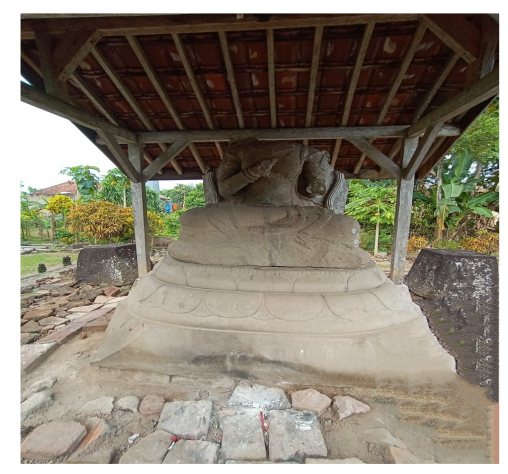

Gambar 1. Arca Prajnaparamitha Sumber: Dokumentasi Pribadi (2021) 
Integrasi Media Peta (Tematik) Persebaran Candi Hindu-

Buddha Di Tulungagung Dengan Pendekatan

Kontruktivisme Dalam Pembelajaran Sejarah

Menurut beberapa sumber Candi Boyolongu merupakan pendharmaan dari Gayatri Rajapatni, istri Raden Wijaya sekaligus nenek dari Raja Hayam Wuruk. Gayatri Rajapatni merupakan sosok yang begitu dihormati di Majapahit. Hal dibuktikan dengan adanya upacara sradda. Upacara tersebut dilakukan untuk memperingati wafatnya tokoh, dalam hal ini Gayatri Rajapatni. Kematian Gayatri Rajapatni diperingati secara besar-besaran. Upacaranya berlangsung delapan hari. Secara garis besar upacaranya berisi tentang pemujaan terhadap arwah Gayatri yang dilakukan seluruh anggota keluarga kerajaan dan pejabat. Ada pula acara makan-makan untuk semua pegawai kerajaan hingga abdinya. Sang raja juga memberikan sedekah yang bersumber dari hartanya untuk masyarakat, paling utama untuk pendeta. Upacara diakhiri dengan penempatan arca Prajnaparamitha di candi pendharmaan Gayatri Rajapatni (Putri, 2018). Arca dewi yang berada di Candi Boyolangu terbuat dari batu andesit. Kondisinya bagian kepala dan kedua tangannya telah hilang. Berdasarkan ciri-cirinya arca tersebut adalah arca Prajnaparamita (Istari, 2015).

Prajnaparamita merupakan personifikasi dalam Buddha Mahayana. Prajnaparamita sebenarnya merupakan nama kitab yang didalamnya memuat tentang kebijaksanaan dan pengetahuan tertinggi guna mencapai hakikat adikodrati. Kitab tersebut diwujudkan dalam arca dewi yang cantik. Mengacu pada tradisi Buddha Mahayana yang berkembang di India Selatan. Prajnaparamitha memiliki arti sepuluh kenyataan sempurna yaitu: 1) Dana (kebebasan), 2) Sila (kehidupan yang baik), 3) Ksanti (kesabaran), 4) Virya (kekuatan), 5) Dhyana (meditasi), 6) Prajna (kesempurnaan), 7) Upayakauslya (upaya pembebasan dari hidup yang semu), 8) Pranidhana (ketidaktepatan, perubahan), 9) Bala (kemampuan transedental), 10) Jnana (pengetahuan). Prajnaparamita dikenal pula dengan adi-prajna yakni lambang ilmu pengetahuan yang sempurna dalam lingkungan alam yang dijiwai oleh AdiBuddha maka dalam perwujudan arcanya Prajnaparamitha merupakan gambaran wanita tertinggi dalam Buddha Mahayana. Sebagai dewi yang berkedudukan tinggi maka Prajnaparamitha dimuliakan mengingat sebagai yang menguasai ilmu pengetahuan (Wasisto, 2009).

Kedua, Candi Sanggrahan terletak di Desa Sanggrahan, Kecamatan Boyolangu, Kabupaten Tulungagung pada ketinggian $104 \mathrm{mdpl}$. Secara koordinat terletak $8^{\circ} 6^{\prime}$ 58,000" LS dan $111^{\circ} 55^{\prime}$ 2,500" BT. Candi Sanggrahan dikenal pula dengan candi Cungkup. Laporan mengenai Candi Sanggrahan pertama kali dilakukan oleh J. Knebel tentang penemuan lima buah arca Dhyani-Buddha yang pada bagian kepalanya telah hilang. Terkait penemuan 
arca Izza juga mengungkapkan jika di candi Sanggrahan ditemukan lima arca Tanthagata. Arca ini berhubungan dengan ajaran kebijaksanaan dan kasih sayang (Izza, 2016). Menurut konteks kesejarahannya dalam buku History Of Java keberadaan Candi Sanggrahan juga disebutkan sebagai tempat menyimapan jenazah atau mengenang kembali mereka yang telah tiada (Raflesh, 2019). Terdapat pendapat lainnya jika Candi Sanggrahan didirikan sebagai tempat peristirahatan para pembawa jenazah Gayatri Rajapatni. Jenazah tersebut dibawa dari keraton Majapahit yang kemudian dibakar di kawasan Boyolangu. Mengenai jenazah Gayatri dapat dihubungkan dengan Candi Boyolangu yang tidak jauh dengan Candi Sanggrahan sebagai tempat pendharmaan dari Gayatri Rajapatni (Bappeda Tulungagung, 2017).

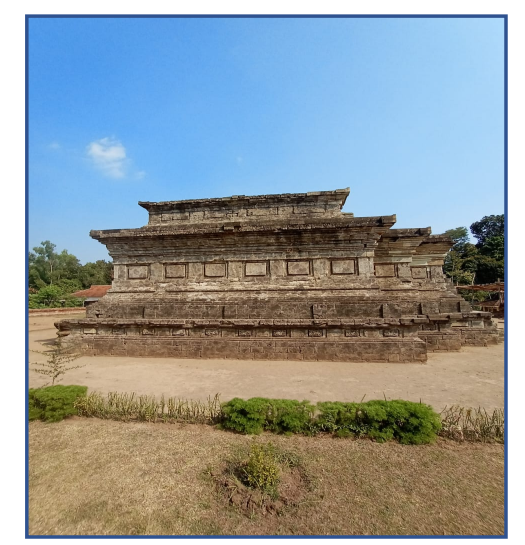

Gambar 2. Candi Sanggraham Sumber: Dokumentasi Pribadi (2021)

Candi Sanggrahan kemungkinan didirikan pada zaman Majapahit. Hal ini mengacu pada Nagarakrtagama yang menyebutkan adanya bangunan dengan nama Kuti Sanggarha. Dalam konteks keagamaan Candi Sanggrahan diibaratkan sebagai Gunung Mahameru. Apabila dihubungkan dengan konsep Budhisme merupakan titik pusat yang dikelilingi lautan. Jika dikembalikan ke masa lalu kawasan sanggrahan merupakan rawa-rawa dan puncaknya adalah tempat bersemayamnya para dewa (Izza, 2016). Sisi arsitekturnya pada bagian luar tubuh candi dapat dijumpai beberapa panil kosong, kemungkinan panil tersebut sebagai calon dipahatkannya relief tapi belum terlaksana. Terdapat satu relief yang melukiskan seekor singa dengan penonjolan telinganya yang lebar distilasi sulur. Mengacu pada konsep kepercayaan Buddha, singa merupakan kendaraan sang Buddha ke nirwana. Singa tersebut merupakan representasi dari Sang Buddha yakni Sidharta Gautama. Ia dikenal sebagai singa keluarga sakya yang melambangkan kekuatan, keberanian, kemenangan, 
Integrasi Media Peta (Tematik) Persebaran Candi Hindu-

Buddha Di Tulungagung Dengan Pendekatan

Kontruktivisme Dalam Pembelajaran Sejarah

serta melindungi para penganut Buddha. Adanya relief singa juga menegaskan bahwa Candi Sanggrahan merupakan candi dengan corak Buddha (Istari, 2015).

Ketiga, Candi Meja berada di kawasan komplek kepurbakalaan Gunung Wajak. Secara administratif berlokasi di Desa Wajak Kidul, Kecamatan Boyolango, Tulungagung. Berada pada Koordinat $8^{\circ} 7^{\prime}$ 41,002" LS dan $111^{\circ} 55^{\prime}$ 0,998" BT. Pada ketinggian $138 \mathrm{mdpl}$. Candi Meja bentuknya menyerupai batur yang dipotong dari batuan monolit. Ukuran baturnya $3 \times 3 \mathrm{~m}$, tingginya 1 meter, memiliki anak tangga berada di sisi barat tetapi kondisi undakannya sudah tidak utuh. Kondisi Candi Meja tersisa bagian baturnya, denahnya bujur sangkar, akan tetapi pada sisi tenggaranya sudah mengalami kerusakan. Pada bagian dinding batur terdapat hiasan deretan tapak dara (mirip salib Yunani). Mengenai kondisi candi menja yang tanpa atap dimungkinkan jika candi dibuat sebagai tempat para rsi bertapa (Sedyawati et al., 2013).

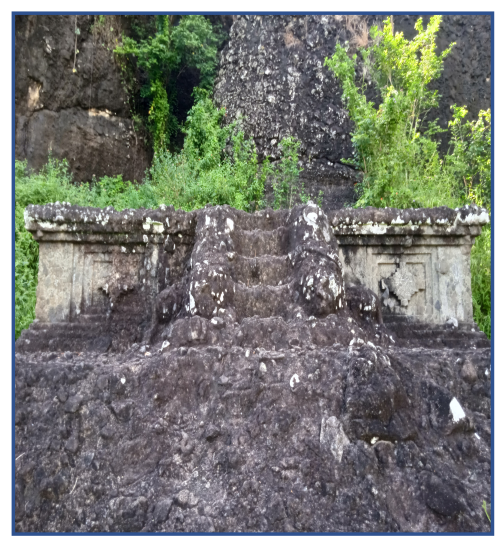

Gambar 3. Candi Meja

Sumber: Dokumentasi Pribadi (2021)

Guna mendapatkan pemahaman yang utuh terkait keberadaan dan fungsi dari candi Meja perlu dikaitkan dengan keberadaan bangunan arkeologis lainnya yang berada di kawasan gunung Wajak seperti Goa Selomangleng, Goa Tritis, Goa Pasir dan Candi Dadi. Mengenai sejarahnya candi meja memiliki hubungan erat dengan Goa Selomangleng yang berada di bawahnya sekitar 30 meter. Mengacu pada penelitian yang dilakukan Izza (2014) dinyatakan bahwa goa selomangleng dibangun pada masa pemerintahan pra Kediri dan terus digunakan pada masa Majapahit.

Diperkirakan bangunan ini dibangun pada masa Airlangga dari Kerajaan Mataram Kuno Jawa Timur pada abad XI atau 1019-1042. Sumardjo (2004) menjelaskan bahwa keberadaan Candi Meja berhubungan dengan karsyan. Rsi merupakan tokoh memiliki yang memiliki pengetahuan tinggi tentang 
keagamaan. Agama golongan Rsi pada dasarnya adalah Hindu Saiwa dari aliran Saiwa Siddhanta. Kaum Rsi menjalani hidup dengan mengasingkan diri dunia ramai guna menjalankan tapa serta mempelajari kitab-kitab keagamaan secara mendalam. Laku Rsi dikenal dengan wanaprastha dalam perjalanan caturasrama (Brahmacari, Grhasta, Wanaprasta, Bhisukha). Wanaprastha berhubungan dengan laku sederhana atau mengasingkan diri dari kehidupan dunia.

Keempat, Candi Dadi berada di kompleks kepurbakalaan Gunung Walikukun, yaitu di puncak Pegunungan Wajak. Secara administratif Candi Dadi berada di Desa Wajak Kidul. Koordinatnya berada di $8^{\circ} 7^{\prime} 48,738^{\prime \prime}$ LS $111^{\circ}$ 55' 36,246" BT. Ketinggian 400 mdpl (Sedyawati et al., 2013). Sampai saat ini belum pernah ada yang mampu menunjukan angka tahun pembangunan Candi Dadi. Berdasarkan perkiraan dengan membandingkan banyaknya tinggalan purbakala di kaki Pegunungan Wajak Kidul yang berasal dari abad ke 14-15, bisa ditafsirkan Candi Dadi berasal dari abad ke-15 M (Munandar, 2015). Hal ini dibuktikan dengan kepurbakalaan di kaki Pegunungan Wajak memiliki ragam hias yang selanggam dengan Candi Dadi, yakni dari masa Majapahit. Dengan demikian candi Dadi dibangun pada masa pemerintahan Majapahit. Van Stein Callenfels mengungkapkan jika struktur yang tersisa dari Candi Dadi merupakan sebuah stupa raksasa yang berdiri di puncak bukit. Pendapat tersebut mengacu pada denah dasar candi yang berbentuk empat persegi panjang, di atasnya terdapat batur segi delapan, tanpa tangga naik, dan terdapat lubang di tengahnya. Apabila Candi Dadi benar sebagai stupa maka bisa disimpulkan bangunan ini bercorak Buddha. Argumen tersebut sesuai pula dengan Soekmono (2017) mengenai Candi Dadi besar pula kemungkinannya bahwa bangunan inipun hanya merupakan lambang kebesaran belaka dari agama Buddha. 
Integrasi Media Peta (Tematik) Persebaran Candi Hindu-

Buddha Di Tulungagung Dengan Pendekatan

Kontruktivisme Dalam Pembelajaran Sejarah

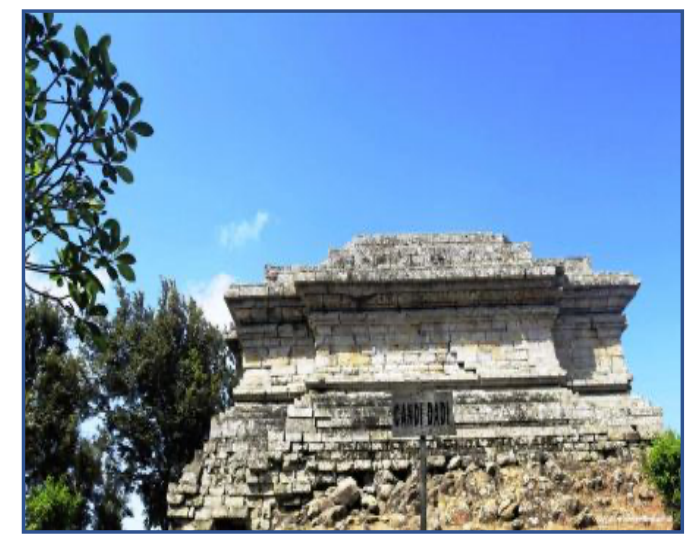

Gambar 4. Candi Dadi

Sumber: Dokumentasi Pribadi (2021)

Munandar (2016) memiliki pandangan lain jika Candi Dadi sebagai Mahavedi jenis Garhapatya dengan tungku (chitti) lingkaran di tengahnya sebagai tungku pembakaran sajian persembahan bagi para dewa. Dalam konteks kehidupan masyarakat yang menggunakan candi Dadi lebih kepada golongan Rsi. Para Rsi yang bersemanyam di berbagai pertapaan di sekitar Candi Dadi yang kemudian untuk waktu tertentu berkunjung ke Candi Dadi untuk menggelar upacara guna mempersembahkan korban dengan membakar benda-benda sesajian dalam lubang tengah candi. Argumennya didasarkan pada analisis kontekstual dengan temuan-temuan kepurbakalaan lain yang masih ada di sekitar Candi Dadi (Goa Tritis, Goa Pasir, dan Goa Selomangleng) maupun analisis terhadap sisa-sisa struktur di lereng bawah Candi Dadi. Dengan demikian kemungkinannya Candi Dadi merupakan bangunan suatu karsyan, keberadaan Candi Dadi sebagai bangunan paling penting yang berada di lereng teratas atau puncak bukit (Munandar \& Wahyudi, 1995). Debat mengenai corak keagamaan serta peran utama candi nampaknya masih terus berlanjut hingga kini. Belum ada kajian terbaru yang mampu mengungkap secara jelas fungsi Candi Dadi pada masa Majapahit. Hal demikian, secara tidak langsung dapat dikatakan sebagai keistimewaan yang dimiliki Candi Dadi. Mengenai nama karsyan yang berada di Candi Dadi dan sekitarnya masih memerlukan penelitian lebih mendalam guna mengungkapkan peranannya dalam konteks masyarakat Majapahit (Munandar \& Wahyudi, 1995).

Kelima, Candi Mirigambar berlokasi di Desa Mirigambar, Kecamatan Sumbergempol, Tulungagung, Jawa Timur. Secara astronomis berada di $8^{\circ} 8^{\prime}$ 2,700" LS $111^{\circ}$ 58' 32,400" BT Ketinggian 123 mdpl. Mengenai tahun berdirinya Candi Mirigambar dapat diidentifikasi pada halaman candi. Di sana masih dapat dijumpai balok-balok batu yang mempunyai pahatan angka tahun 1214 
Saka (1207 M), 1310 Saka (1388 M), dan 1321 Saka (1399 M) (Sedyawati et al., 2013). Mengacu pada pendapat Hidayat, (2009) bahwa Candi Mirigambar telah difungsikan sejak masa pemerintahan Kediri akhir sampai masa Majapahit. Angka 1399 M menunjukkan masa pemerintahan Wikramawardhana yang merupakan menantu dari Rajasanegara (Hayam Wuruk). Mengenai pembangunan memang belum ada pendapat pasti. Salah satu hal yang menguatkan adalah penemuan prasasti lempeng tembaga di sekitar candi yang menyebut raja Wikramardhana. Secara arsitektur bentuk candinya persegi panjang yang memiliki tiga tingkat, arah hadap candi ke barat dengan tujuh anak tangga, kondisi belakang candi tidak utuh.

Pada dinding candinya terdapat panil relief. Meskipun beberapa bagian candi telah mengalami kerusakan tetapi masih terdapat keindahan hiasannya. Menurut perkiraan panil relief yang terdapat pada Candi Mirigambar berjumlah sekitar 11 bidang, tetapi rata-rata panil telah mengalami kerusakan. Panil yang terkenal berada di sisi depan teras pertama yang melukiskan adegan kisah panji. Secara narasi menurut Kieven, (2014) cerita panji menggambarkan persaingan Panji dengan raja dari Magadha. Raja tersebut berkeinginan menikahi tunangan dari Raden Panji yaitu Raden Galuh. Raden Panji berusaha dibunuh oleh Raja Magadha dengan cara dibelitkan pada akar pohon dan dilemparkan ke air sampai Raden Panji Tenggelam. Kemudian Raden Panji ditemukan oleh nelayan dari Raden Galuh di tepi sungai dengan kondisi selamat. Raden Galuh merawat Raden Panji sampai sehat seperti sedia kala dan Raden Panji diberi julukan dengan nama Waseng Sari. Berikutnya Raden Panji bersama-sama dengan pasukannya berperang melawan Raja Magadha yang menyerang Daha. Setelah melalui beberapa pertempuran akhirnya Raden Panji memenangkannya dan dapat mempersunting Raden Galuh. Cerita panji tersebut memiliki nilai-nilai positif kehidupan yang sangat baik untuk diterapkan dalam kehidupan sehari-hari seperti kerja keras dan tanggung jawab.

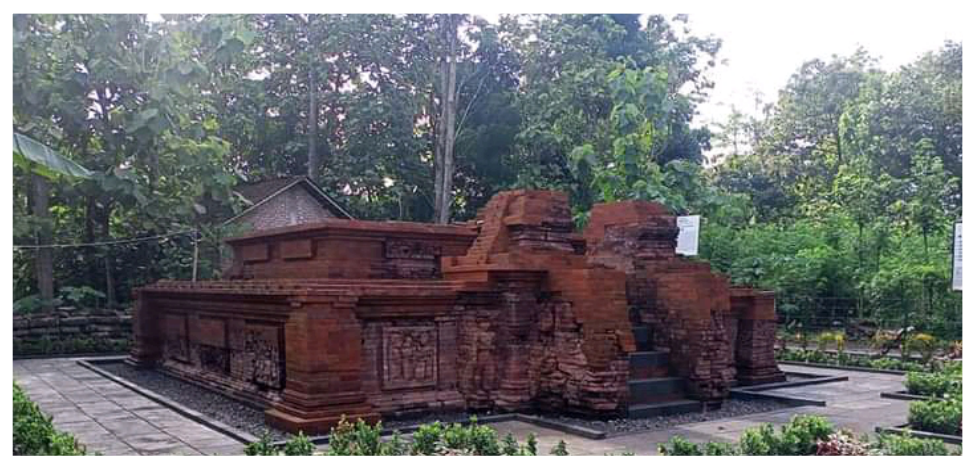

Gambar 5. Candi Mirigambar Sumber: Dokumentasi Pribadi (2021) 
Integrasi Media Peta (Tematik) Persebaran Candi Hindu-

Buddha Di Tulungagung Dengan Pendekatan

Kontruktivisme Dalam Pembelajaran Sejarah

Candi Mirigambar kaitannya dengan konteks keagamaan memiliki corak sebagai candi Hindu. Hal ini dibuktikan dengan cerita panji yang sangat identik dengan agama Hindu, sebagaimana cerita panji Wanban Wideya yang menunjukan jika Panji melaksanakan pemujaan Dewa Siwa setelah berperang melawan raja Lasem. Dewa Siwa merupakan dewa tertinggi dalam agama Hindu. Bukti lainnya terkait pembacaan panil relief candi Mirigambar secara pradaksina atau searah jarum jam yang memiliki tujuan pemujaan terhadap dewa, dalam hal ini dewa Siwa sebagai dewa tertinggi dalam agama Hindu (T. Hidayat, 2009).

Keenam, Candi Ampel berlokasi di Dusun Ngampel, Desa Joho, Kecamatan Kalidawir, Tulungagung, Jawa Timur. Secara astronomis berada pada koordinat $8^{\circ} 8^{\prime}$ 5,028” LS 111 53' 28,932" BT. Candi Ampel berada pada ketinggian. 116 mdpl. Secara geografis candi ini berada di kaki Perbukitan Walikukun. Mengenai pembangunan candi belum ada datamya akan tetapi dapat diperbandingkan dengan temuan di sekitar candi berupa arca Parwati yang berinskripsi tahun 1331 Saka (1409 Masehi), arca Bima, arca Siwa, arca Parwati, dan prasasti. Dengan demikian diperkirakan candi Ampel merupakan peninggalan masa Majapahit (Sedyawati et al., 2013). Merujuk pada jenis arca yang ditemukan bisa disimpulkan jika corak keagamaan dari Candi Ampel adalah Hindu. Angka tahun 1409 M pada arca Parwati jika dihubungkan dengan pemerintahan Majapahit maka pada periode tersebut merupakan masa pemerintahan Wikramardhana.

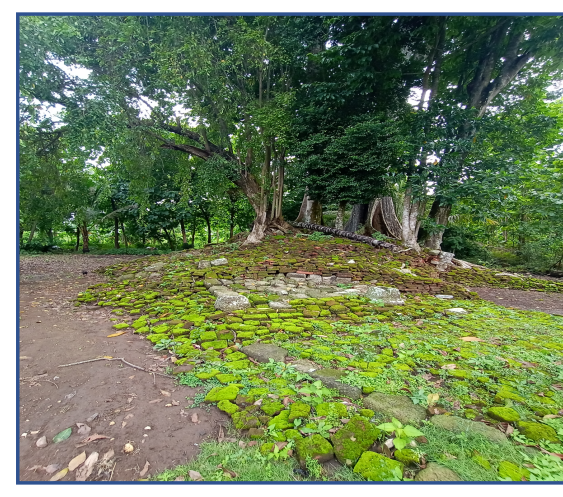

Gambar 6. Candi Dadi

Sumber: Dokumentasi Pribadi (2021)

Candi Ampel adalah candi tunggal yang tersusun dari bahan bata dan batu andesit. Kondisi candi tinggal bagian dasar hancur serta sulit diidentifikasi bentuknya dan arah hadapnya. Pada sekitar reruntuhan bata masih bisa ditemukan umpak batu sejumlah tujuh buah, yoni, dan fragmen arca. 
Meskipun kondisi bata candi telah ditumbuhi pohon-pohon besar, pada sisi selatan reruntuhan masih terindetifikasi sebagai dinding candi yang masih insitu membujur barat-timur. Pada dinding tersebut ditemukan hiasan ornamen berupa sulur-suluran dan pola geometris. Untuk mengidentifikasi fungsi candi cukup sulit. Sementara adanya umpak batu menunjukkan adanya pemanfaatan bangunan lain yang digunakan untuk menaungi bagian atas candi (Sedyawati et al., 2013).

Ketujuh, Candi Penampihan terletak di Desa Geger, Kecamatan Sendang, Kabupaten Tulungagung. Secara astronomis terletak di $08^{\circ} 08^{\prime} 03,3^{\prime \prime} \mathrm{LS}, 111^{\circ} 58^{\prime}$ 33, 0" BT. Candi Penampihan berada pada ketinggian 1048 mdpl. Di Sekitar kompleks candi terdapat prasasti yang memuat angka tahun 980 Saka (1058 M), kondisi hurufnya telah aus, menurut beberapa ahli prasasti tersebut berupa replika atau tinulad yang tujuannya sebagai sarana legitimasi kekuasaan raja. Candi Penampihan didirikan dengan memanfaatkan sisa punden berundak masa prasejarah. Sisi historis situs dapat direkonstruksi dari prasasti yang ada di sekitar bangunan. Terdapat prasasti yang berasal dari batu andesit dan lempengan tembaga. Prasasti dari batu andesit dikeluarkan oleh Rakai Watukura pada tahun 820 Saka $(898 \mathrm{M})$ yang isinya tentang keberadaan mandala atau bangunan suci, yang terdapat di lereng Gunung Wilis. Tokoh yang naik tahta dari kerajaan Mataram Kuna karena perkawinan ini diyakini memang meluaskan kekuasaan ke Jawa Timur. Prasasti Penampihan yang dipahatkan diatas tujuh lempengan tembaga atau disebutnya prasasti Sarwadharma berangka tahun 1191 Saka, tepatnya dikeluarkan pada tanggal 31 Oktober 1269. Didalamnya disebutkan tentang kondisi masyarakat yang terbagi dalam kasta atau tingkatan kelompok masyarakat (BPCB Jawa Timur, 2016). Melihat angka tahun yang ditemukan di sekitar kompleks candi diperkirakan bangunan tersebut telah difungsikan sejak masa Mataram Kuno sampai Singhasari.

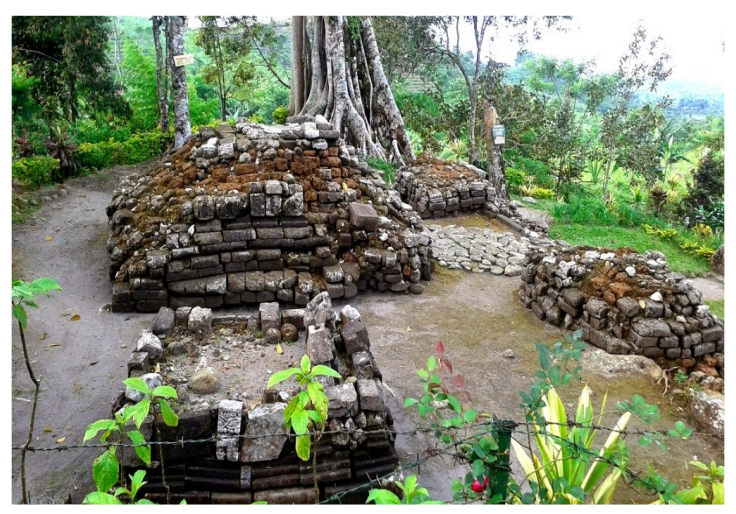

Gambar 7. Candi Penampihan Sumber: Dokumentasi Pribadi (2021) 
Integrasi Media Peta (Tematik) Persebaran Candi Hindu-

Buddha Di Tulungagung Dengan Pendekatan

Kontruktivisme Dalam Pembelajaran Sejarah

Mengacu pada cerita yang berkembang di masyarakat sekitar disebutkan jika ada seorang pembesar dari Wengker (Ponorogo) bertujuan melamar Dewi Kilisuci dari Kerajaan Kediri. Rombongan dari Wengker berangkat dengan segala perlengkapan untuk lamaran dan perkawinan. Ketika sampai di tengah perjalanan rombongan mengutus seorang kurir guna mengutarakan tujuan sang pembesar. Kabar yang didapat kurang mengenakan yaitu lamarannya ditolak oleh Dewi Kilisuci. Sang pembesar mengalami kegundahan sehingga tidak bersedia kembali ke kampung halamannya. Beliau memutuskan untuk mendirikan bangunan suci dan menghabiskan sisa hidupnya disana. Hal ini berkenaan dengan penamaan Candi Penampihan, yang berasal dari kata 'tampik' yang artinya tolak. Penolakan atau penampikan yang lama kelamaan menjadi penampihan. Maka Candi penampihan sering disebut juga dengan Candi Asmarabangun. Pemberian nama tersebut berhubungan dengan cerita rakyat pembangunannya dikaitkan dengan tokoh yang tengah dilanda asmara (BPCB Jawa Timur, 2016). Candi menghadap ke barat dengan struktur bangunan candi berupa punden berundak dengan tiga teras, serta teras paling tinggi terletak di bagian timur. Pada teras terbawah, ada suatu prasasti dengan tinggi 1,50 meter berbahan batu andesit yang diletakkan pada alas batu bundar.

Terdapat tangga yang terbuat dari batu andesit yang menghubungkan antar teras. Pada teras paling atas, dapat ditemukan sisa bangunan candi induk serta dua buah candi perwara yang telah ambruk. Penampakan candi induk disangga seekor kura-kura raksasa dengan kondisi kepalanya telah lenyap, di atas kura-kura ada sepasang dragon mengenakan mahkota. Keberadaan kurakura yang melandasi bangunannya menunjukan jika candi ini bercorak Hindu. Dalam mitologi Hindu, kura-kura merupakan salah satu awatara penjelmaan Wisnu. Kaitannya dengan prasasti yang terbuat dari batu andesit yang berukuran besar yang terdapat di percandian ini. Secara keseluruhan candi induk ini melukiskan insiden Samodramanthana ialah pemutaran air laut buat mencari air kehidupan atau Amerta (Istari, 2015). Sementara Munandar (2004) menghubungkan relief kura-kura dengan cerita tantri kamandaka yang syarat dengan nilai moral terkait pertemanan antar angsa dan kura-kura. Terdapat beberapa relief yang dipahatkan pada panil bangunan candi, namun sebab posisinya telah tidak teratur sehingga agak sulit dikenal ceritannya. Data dari penjaga candi, relief itu melukiskan narasi Sudamala. bangunan suci Hindu itu "ditumpangkan" di atas punden berundak. Salah satunya wujud jenis hias noncerita yang bisa dikenal merupakan wujud meander, sebagai wujud macam hias geometris. Meander menyerupai dengan wujud" pinggir awan" riasan yang dipahatkan mendatar mengitari pelipi bangunan candi, sebagai pengisi 
bidang saja. Lokasi Candi Penampihan yang berundak teras merupakan bukti tentang berlangsungnya kebudayaan megalitik di Tulungagung.

\section{Implementasi Peta (Tematik) Persebaran Candi Hindu-Buddha Dengan Pendekatan Konstruktivisme}

Implementasi pembelajaran sejarah dengan media peta tematik persebaran candi Hindu-Buddha dengan dengan pendekatan konstruktivisme mengacu pada Kompetensi Dasar 3.6 menganalisis perkembangan kehidupan masyarakat, pemerintahan, dan budaya pada masa kerajaan-kerajaan Hindu dan Buddha di Indonesia serta menunjukkan contoh bukti-bukti yang masih berlaku pada kehidupan masyarakat Indonesia masa kini. KD tersebut digunakan di kelas $X$ semester 1. Adapun IPK dalam pembelajarannya meliputi: 3.6.1. Menganalisis pengaruh Hindu dan Buddha Di Indonesia. 3.6.2. Mengenali bukti-bukti pengaruh Hindu dan Buddha yang masih ada sampai masa kini. Alokasi waktu pembelajaran selama $2 \times 45$ menit dalam satu pertemuan. Proses implementasi pembelajaran melalui tiga fase yaitu pendahuluan, kegiatan inti, dan penutup. Integrasi media peta (tematik) dengan pendekatan konstruktivisme yang digunakan adalah model siklus belajar (Supardan, 2016).

Tahap pendahuluan langkah pembelajaran diawali dengan kegiatan apersepsi oleh guru dengan pemberian pertanyaan berupa "Sebutkan peninggalan sejarah di Kabupaten Tulungagung mulai dari masa pra-aksara sampai kontemporer?, akan lebih baik lagi jika kalian (para siswa) menyebutkan peninggalannya beserta konteks zamannya". Ketika para siswa mulai menunjukan bukti-buktinya, guru mengarahkan untuk fokus ke masa Hindu-Buddha. Pada tahap kegiatan inti mulai masuk pendekatan konstruktivisme fase pertama yaitu discovery: Pada tahap ini para siswa diberikan dorongan untuk membuat hipotesis maupun pertanyaan terkait bukti-bukti peninggalan masa HinduBuddha yang masih dapat ditemui. Para siswa diberikan stimulus. Misalkan, Agama Hindu-Buddha berasal dari mana? Kedatangan agama Hindu-Buddha membawa pengaruh apa saja? Bagaimana menurut anda pengaruh tersebut ke Nusantara? Nilai-nilai kehidupan apa yang anda peroleh setelah belajar terkait buktibukti peninggalan Hindu-Buddha.

Fase kedua yaitu pengenalan konsep: pada tahap ini siswa mengkaji konsep baru terkait pengaruh Hindu-Buddha di Nusantara melalui bimbingan guru. Konsep-konsep yang menjadi bahan diskusi diantaranya: Pengaruh Hindu-Buddha di bidang tata pemerintahan, kepercayaan, bahasa dan tulisan, kesusastraan, dan seni bangunan. Para siswa juga dibimbing untuk mancari 
Danan Tricahyono, Akhmad Arif Musadad, Triana Rejekiningsih

Integrasi Media Peta (Tematik) Persebaran Candi Hindu-

Buddha Di Tulungagung Dengan Pendekatan

Kontruktivisme Dalam Pembelajaran Sejarah

konsep bagian-bagian yang menyertai topik bahasan tersebut. Misalkan, perbandingan tata pemerintahan, kepercayaan masa pra-aksara dan Hindu-Buddha, bentuk kesusastraan, bahasa dan tulisan, serta struktur bangunan seperti candi.

Fase ketiga yaitu aplikasi konsep: pada tahap ini siswa menggunakan media peta persebaran candi Hindu Buddha di Tulungagung.

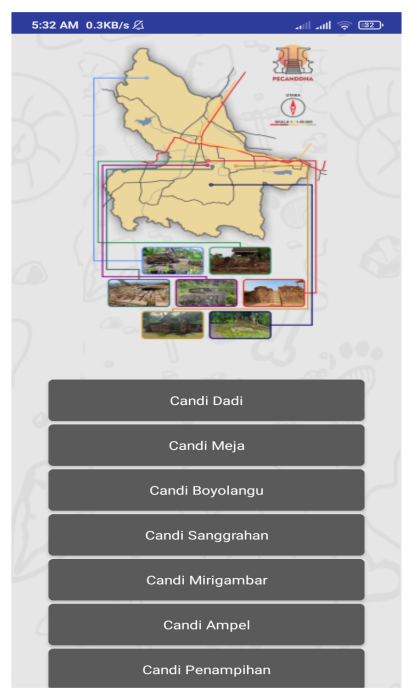

Gambar 8. Media Peta (Tematik)

Sumber: Dokumentasi Pribadi (2021)

Siswa menyebutkan nama-nama candi yang berada di Kabupaten Tulungagung sebagai bukti peninggalan yang berada di sekitarnya beserta lokasi tempat candi berada. Guna melengkapi perspektif yang dimiliki, siswa melihat peta kabupaten Tulungagung beserta kenampakan titik lokasi candi. Melalui proses interaksi antara pengetahuan yang berada dalam memori otaknya dengan media peta diharapkan muncul dialektika sehingga para siswa dapat memberikan penjelasan-penjelasan baru terkait latar belakang sejarah keberadaan candi. Guru memberikan bimbingan berupa konsep dalam sejarah menyangkut tempat, ruang, dan waktu. Dengan demikian keberadaan candi nantinya dapat direkonstruksi ceritanya berdasarkan struktur tempat dan ruangnya baru kemudian ditentukan tahunnya.

Proses interakasi siswa dengan media peta menjadikannya mengerti tentang konsep pembangunan candi yang rata-rata berada di lokasi dekat dengan bukit ataupun pegunungan. Dengan demikian siswa mampu untuk memberikan pendapat baru terkait alasan pembangunan yang mayoritas 
berlokasi di perbukitan dan pegunungan. Kemampuan menjelaskan alasan pembangunan akan menstimulus pikirannya dalam merekonstruksi kehidupan sosial di masa lalu terkait fungsi candi. Contohnya: siswa dapat menganalisis fungsi candi Meja yang berada di kawasan perbukitan Walikukun sebagai tempat peribadatan kaum Rsi, Siswa dapat menganalisis fungsi candi Gayatri yang berada di kecamatan Boyolangu, Siswa dapat menganalisis keberadaan candi Mirigambar, Siswa dapat menganalisis candi Sanggrahan, Siswa dapat menganalisis candi Dadi, siswa dapat menganalisis Candi Ampel, siswa dapat menganalisis candi Penampihan.

Kemampuan siswa menganalisis setiap fungsi dan keberadaan candi menjadikannya mampu untuk merekonstruksi kehidupan masyarakat yang mengiringi keberadaan Candi dan melihat Tulungagung masa Hindu-Buddha dalam hubungannya dengan sejarah nasional Indonesia. Kemampuan tersebut dilihat dari indikator berupa pemahaman siswa tentang pemerintahan (kerajaan) yang membangun candi, pemahaman siswa tentang fungsi candi dalam hubungannya dengan ritual keagamaan, misalnya membedakan fungsi candi sebagai petirtaan atau pendharmaan. Dengan begitu siswa memperoleh pemahaman yang komprehensif mengenai kehidupan sosial masyarakatnya. Kehidupan sosial masa Hindu-Buddha dengan segala isinya memiliki nilainilai positif yang bisa diteladani oleh para siswa. Nilai-nilai tersebut sebagai pengembangan sikap sosial seperti empati terhadap tokoh sejarah maupun benda sejarah. Sikap sosial bermanfaat sebagai pondasi dasar dalam berinteraksi lebih luas dengan sesama siswa maupun orang lain dalam kehidupan berbangsa dan bernegara. Ketika pada tahap ini guru dapat memberikan scaffolding. Berkenaan dengan teknik bimbingan, saat siswa secara level pengetahuannya meningkat maka semakin sedikit bimbingan yang diberikan (Daryanto \& Karim, 2017).

\section{Simpulan}

Tulungagung memiliki tujuh buah situs candi yang tersebar di beberapa kecamatan. Keberadaan candi-candi tersebut memiliki potensi untuk digunakan sebagai konten media peta (tematik) persebaran situs. Media pembelajaran berbasis peta (tematik) persebaran situs candi dengan pendekatan konstruktivisme memiliki keunggulan untuk mengoptimalkan kemampuan siswa memahami aspek waktu, spasial, dan tempat sebagai modal utama mendapatkan pemahaman sejarah secara komprehensif. Pemahaman yang baik terkait materi sejarah menjadikan pembelajaran lebih bermakna untuk siswa. Sehingga para siswa dapat merefleksikan materi sejarah untuk diambil nilai-nilai positifnya sebagai bekal menjalani kehidupan di masa kini 
Danan Tricahyono, Akhmad Arif Musadad, Triana Rejekiningsih

Integrasi Media Peta (Tematik) Persebaran Candi Hindu-

Buddha Di Tulungagung Dengan Pendekatan

Kontruktivisme Dalam Pembelajaran Sejarah

dan masa depan. Selain itu juga, persinggungan siswa dengan materi lokal membuat siswa lebih mengenal potensi sejarah yang berada di sekitarnya. Harapannya bisa meningkatkan kesadaran sejarah lokal. Saran untuk peneliti lain bisa memanfaatkan potensi sejarah lokal di daerahnya sebagai konten (isi) materi media pembelajaran yang luarannya dapat meningkatkan kesadaran sejarah siswa.

\section{Daftar Rujukan}

Agung, L. (2015). Sejarah Kurikulum Sekolah Menengah Di Indonesia: Sejak Kemerdekaan Hingga Reformasi. Yogyakarta: Ombak.

Arsyad, A. (2019). Media Pembelajaran. Depok: Rajawali Pers.

Bandarsyah, D. (2014). Aktualisasi Pendidikan Karakter Melalui Pembelajaran Sejarah. ISTORIA: Jurnal Pendidikan Dan Ilmu Sejarah, 1(Maret), 1-17. https://doi.org/10.1017/CBO9781107415324.004

Ciputra, A., \& Riyanto, Y. (2020). Pengembangan Media Peta Puzzle dengan Pendekatan Contextual Teaching and Learning (CTL) Untuk Meningkatkan Hasil Belajar. 5(1), 730-739.

Creswell, J. W. (2012). Educational Research (Fourth). Boston: Pearson Education, Inc.

Darmawan, M., Daryaka, S., \& Mustofa, F. (2016). Atlas Budaya Edisi Candi: Meneropong Candi dari Aspek Geospasial. Bogor: Badan Informasi Geospasial. Daryanto, \& Karim, S. (2017). Pembelajaran Abad 21. Yogyakarta: Gava Media.

Gerlach, \& Ely. (1980). Teaching \& Media: A Systematic Approach. Boston: Pearson Education, Inc.

Hasan, S. H. (2019). Pendidikan Sejarah untuk Kehidupan Abad Ke 21. HISTORIA: Jurnal Pendidik Dan Peneliti Sejarah, II(2), 61-72.

Hidayat, A. (2018). Penggunaan Media Peta Pengaruhnya Terhadap Motivasi Belajar Sejarah Pada Sma Islam Pb. Soedirman Cijantung Jakarta Timur. Jurnal Candrasangkala Pendidikan Sejarah, 4(1), 14. https:// doi.org/10.30870/candrasangkala.v4i1.3427

Hidayat, T. (2009). Candi Mirigambar: Tinjauan Arsitektur Percandian Majapahit Abad Ke 14-15 M. Universitas Indonesia.

Istari, T. M. R. (2015). Ragam Hias Candi-Candi di Jawa: Motif dan Maknanya (B. Sulistyanto, Ed.). Yogyakarta: Kepel Press.

Izza, N. A. (2014). Gaya Arsitektur Gua Selomangleng Tulungagung Sebagai Pertapaan Masa Mataram Kuno Jawa Bagian Timur dan Muatan Pendidikannya. Jurnal Sejarah Dan Budaya, Vol. 8 No., 176-191.

Izza, N. A. (2016). Karakteristik Bangunan Suci Bercorak Hindu- Buddha Di Gunung Penanggungan Dan Gunung Wajak: Sebuah Tinjauan Perbandingan. Kapata Arkeologi, 12(1), 1-14.

Jawa Timur, B. (2016). Candi Penampihan Tulungagung. Retrieved March 20, 2021, from https://kebudayaan.kemdikbud.go.id/bpcbjatim/candipenampihan-kabupaten-tulungagung/ 
Kieven, L. (2014). Menelusuri Panji Di Candi-Candi: Relief Figur Bertopi di CandiCandi Zaman Majapahit. Jakarta: Kepustakaan Populer Gramedia.

Kurniawan, I. S., Suryani, N., \& Djono. (2019). Pengembangan Media Peta Sejarah Berbasis Macromedia Flash Sebagai Sarana Siswa Belajar Mandiri. 22(1), 1-7.

Mohammed, S. H., \& Kinyo, L. (2020). The Role Of Constructivism In The Enhancement Of Social Studies Education. Journal of Critical Reviews, 7(7), 249-256.

Munandar, A. A. (2004). Karya Sastra Jawa Kuno Yang Diabadikan Pada Relief Candi-Candi Abad Ke-13 - 15 M. Jurnal MAKARA, Sosial Humaniora, 8(2), 54-60.

Munandar, A. A. (2015). Keistimewaan Candi-Candi Zaman Majapahit. Depok: Wedatama Widya Lestari.

Munandar, A. A. (2016). Toponimi Dalam Kajian Arkeologi. Makalah Disampaikan Dalam Seminar Nasional Toponimi: Toponimi Dalam Perspektif Ilmu Budaya Pada 3 November 2016. Jakarta: Fakultas Ilmu Budaya, Universitas Indonesia.

Munandar, A. A., \& Wahyudi, W. . (1995). Laporan Penelitian Candi Dadi Sebagai Karsyan: Reinterpretasi Fungsional. Jakarta.

Ningsih, Y. E., Sariyatun, \& Sutimin, L. A. (2019). A Needs Analysis Of Historical Learning Media To Reinforce Student's Social Intelligence Using Toponym Of The Surakarta Palace. International Journal of Education and Social Science Research, 2(05), 35-47.

Putri, R. . (2018). Dari Sraddha ke Sadran. Retrieved May 10, 2021, from Majalah Historia website: https:/ / historia.id/amp/kuno/articles/dari-sraddha-kesadran-P140g

Raflesh, S. T. S. (2019). History Of Java. Yogyakarta: Narasi.

Rusdiana, Y. T., \& Heryati, H. (2020). Pengajaran Mengunakan Peta Sejarah dan Brosur Melalui Model PAIKEM (Pembelajaran Aktif, Inovatif , Kreatif dan Menyenamgkan ) bagi Guru di SMP PUTRA MAJU. Dedication : Jurnal Pengabdian Masyarakat, 4(1), 71-80. https://doi.org/10.31537/dedication.v4i1.295

Sedyawati, E., Santiko, H., Djafar, H., Maulana, R., Ramelan, W., \& Ashari, C. (2013). Candi Indonesia Seri Jawa. Jakarta: Direktorat Pelestarian Cagar Budaya dan Permuseuman, Direktorat Jendral Kebudayaan, Kementerian Pendidikan dan Kebudayaan.

Soekmono. (2017). Candi Fungsi dan Pengertiannya. Yogyakarta: Ombak. Sumardjo. (2004). Latar Belakang Keagamaan Kepurbakalaan Lereng Utara Pegunungan Kapur Tulungagung Selatan. Universitas Indonesia.

Supardan, D. (2016). Teori dan Praktik Pendekatan Konstruktivisme dalam Pembelajaran. Edunomic, 4(1), 1-12.

Tulungagung, B. (2017). Candi Di Tulungagung. Retrieved April 19, 2021, from http://bappeda.tulungagung.go.id/detailpost/candi-di-tulungagung

Wasisto, B. L. . (2009). Candi Boyolangu: Tinjauan Arsitektur Dan Arkeologis. Universitas Indonesia.

Widja, I. G. (2018). Pembelajaran Sejarah Yang Mencerdaskan : Suatu Alternatif. 
Danan Tricahyono, Akhmad Arif Musadad, Triana Rejekiningsih

Integrasi Media Peta (Tematik) Persebaran Candi Hindu-

Buddha Di Tulungagung Dengan Pendekatan

Kontruktivisme Dalam Pembelajaran Sejarah

JPSI: Jurnal Pendidikan Sejarah Indonesia, 1(2), 117-134.

Zed, M. (2008). Metode Penelitian Kepustakaan. Jakarta: Yayasan Obor Indonesia. 